Research Article

\title{
Research of Deicing and Melting Snow on Airport Asphalt Pavement by Carbon Fiber Heating Wire
}

\author{
Xin Su, ${ }^{1,2}$ Yong Lai ${ }^{D},{ }^{1}$ Yan Liu, ${ }^{2}$ Daoxun $\mathrm{Ma}^{2}$ and Peng Wang ${ }^{2}$ \\ ${ }^{1}$ China Airport Construction Group Co.,Ltd., Beijing 100101, China \\ ${ }^{2}$ Beijing Super-Creative Technology Co.,Ltd., Beijing 100621, China
}

Correspondence should be addressed to Yong Lai; cacclaiyong@126.com

Received 30 April 2020; Accepted 10 July 2020; Published 27 July 2020

Guest Editor: Meng Guo

Copyright (C) 2020 Xin Su et al. This is an open access article distributed under the Creative Commons Attribution License, which permits unrestricted use, distribution, and reproduction in any medium, provided the original work is properly cited.

In the paper, the method of deicing and melting snow by the carbon fiber heating wire (CFHW) embedded in the airport asphalt pavement is proposed to improve the security of airport operation. The field experiment of deicing and melting snow on the airport asphalt pavement is conducted. Deicing and melting snow, asphalt pavement temperature, ice-free area ratio, and snowfree area ratio are analyzed. Electrical power with $350 \mathrm{~W} / \mathrm{m}^{2}$ is input to the airport asphalt pavement for deicing and melting snow by the CFHW. In the experiment, $3 \mathrm{~mm}$ ice can be melted, and the average infrared ray temperature (IRT) of the airport asphalt pavement surface can achieve an increment of $13.0^{\circ} \mathrm{C}$ in 2.5 hours when the air temperature is from $-7.5^{\circ} \mathrm{C}$ to $-2.2^{\circ} \mathrm{C}$. Snow with $3.2 \mathrm{~mm}$ precipitation can be melted in 2 hours when the air temperature is from $-4.8^{\circ} \mathrm{C}$ to $-3.5^{\circ} \mathrm{C}$, and the asphalt pavement temperature can achieve an increment of $5.9^{\circ} \mathrm{C}$ at the depth of $0.5 \mathrm{~cm}$. The results show that the method of deicing and melting snow on the airport asphalt pavement by the CFHW is practicable in the cold zone.

\section{Introduction}

Ice and snow on the airport asphalt pavement affect aircraft takeoff, landing, and taxiing in winter because ice and snow increase the braking distance of the aircraft. The conventional methods of removing ice and snow by using airport pavement deicing fluid and deicing equipment induce flight delay and need a lot of manpower, deicing fluid, and machinery. It is necessary to conduct timely and high-efficient removal of ice and snow to avoid the adverse effect of deicing fluid and machinery on the airport asphalt pavement [1]. Some scholars study how to improve the performance of bitumen and asphalt mixture to avoid negative effect [2-4]. At the same time, some methods of deicing and melting snow on the pavement have been researched, such as asphalt mixture containing the snow-melting agent [5], hydraulic heating system [6-10], electrically conductive concrete [11-13], carbon fiber grille [14], and CFHW [15-19]. The recent research of deicing and melting snow on the pavement mainly focuses on the CFHW [1]. Zhao et al. studied deicing on the bridge deck and concrete pavement by the CFHW $[15,16]$. In frozen and snowy weather, the results of laboratory and field experiments verified the validity of the electrothermal method of deicing and melting snow on the pavement and bridge deck under an appropriate input power. The authors studied the effects of heat flux, wire spacing, wind speed on the concrete pavement temperature, and deicing on the cement concrete pavement by the CFHW $[1,17,18]$. The authors also studied the snow-melting effect, temperature, and energy distribution along the depth of the airport cement concrete pavement [19]. Due to different materials of airport cement concrete and asphalt pavement, the physical properties, construction methods, and dimensions of two kinds of pavement are also different. These determine the difference of deicing and melting snow between airport cement concrete and asphalt pavement. Therefore, the method of deicing and melting snow by the CFHW requires a study on the application of the airport asphalt pavement. In order to prevent ice and snow accumulation, the temperature of the airport 


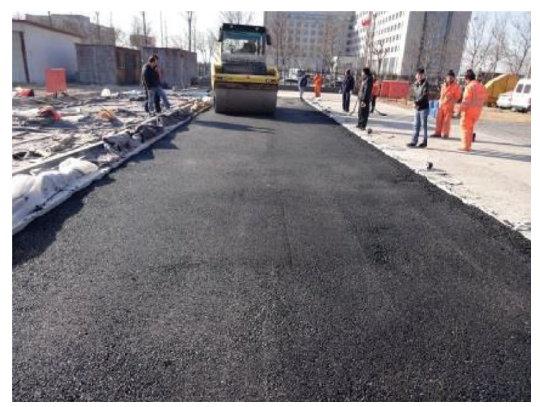

(a)

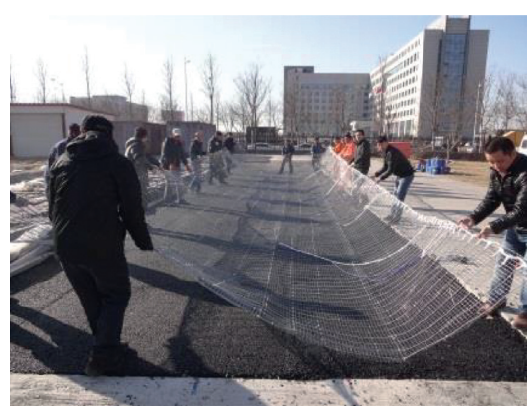

(b)

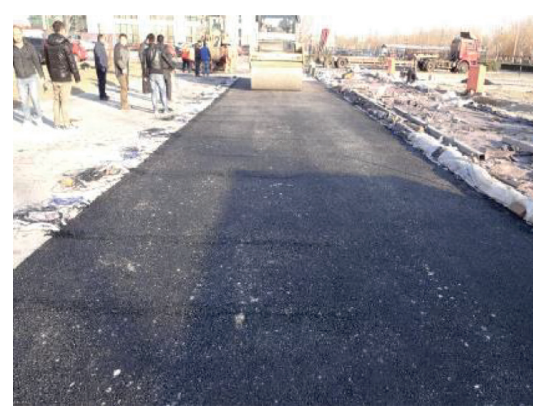

(c)

Figure 1: Airport asphalt pavement construction. (a) Lower layer. (b) Heating system layout. (c) Upper layer.

asphalt pavement surface must maintain above $0^{\circ} \mathrm{C}$. Finally, the full-scale experiments of deicing and melting snow are performed in the real environment of ice and snow.

\section{Materials and Methods}

2.1. Raw Materials. The airport asphalt pavement includes the lower layer and the upper layer, and their thickness is $8 \mathrm{~cm}$ and $7 \mathrm{~cm}$, respectively. The asphalt mixture of the lower layer is AC-25. The asphalt mixture of the upper layer is SMA-13.

2.2. Airport Asphalt Pavement. According to specifications for asphalt pavement design of civil airports, the design and construction of the airport asphalt pavement were implemented. Airport asphalt pavement construction is shown in Figure 1. The airport asphalt pavement is made of $1 \#$ and 2\# asphalt pavement. The sizes of $1 \#$ and $2 \#$ asphalt pavement are $5 \mathrm{~m} \times 10 \mathrm{~m}$. The thickness of the lower layer and the upper layer is $8 \mathrm{~cm}$ and $7 \mathrm{~cm}$, respectively. The CFHW was tied to steel wire gauze, which was buried in the middle of the lower layer and the upper layer. The depth of the CFHW is $7 \mathrm{~cm}$. The spacing of the CFHW is $10 \mathrm{~cm}$. At the depth of $0.5 \mathrm{~cm}$ and $15 \mathrm{~cm}$, six sensors for testing temperature were evenly and vertically buried in the asphalt pavement. The vertical distance between the sensor and the CFHW is $5 \mathrm{~cm}$.

\subsection{Experimental Instrument. The experimental instrument} contains a power distribution control box, infrared thermal image instrument, temperature sensor, temperature data receiver, and adapter. The power distribution control box provides electric energy for the asphalt pavement. The infrared thermal image instrument can measure the temperature of the asphalt pavement surface. The temperature sensor can measure $-50 \sim 150^{\circ} \mathrm{C}$, and its accuracy is $0.1^{\circ} \mathrm{C}$. The temperature data receiver is used to receive temperature information. The temperature data receiver and data adapter are connected. The asphalt pavement temperature is measured by using six temperature sensors at $0.5 \mathrm{~cm}$ and $15 \mathrm{~cm}$ depth, respectively. The airport asphalt pavement temperature is the average temperature of the asphalt pavement at the same depth.

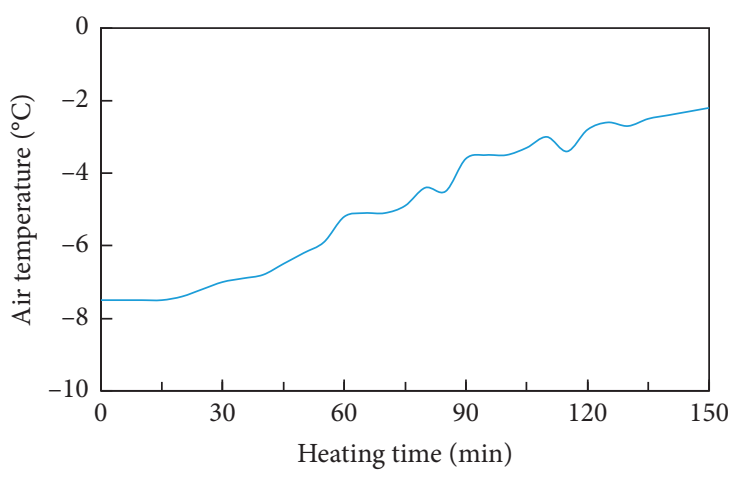

FIgURe 2: Air temperature variation.

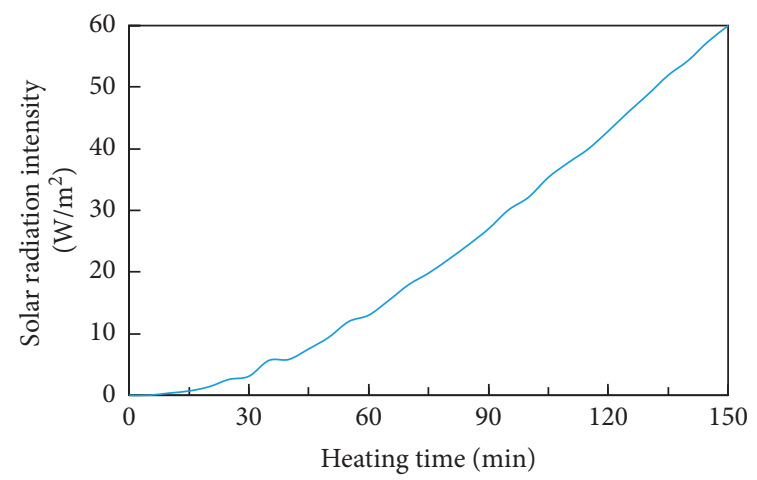

FIgURE 3: Solar radiation intensity variation.

\section{Results and Discussion}

In the test, each circuit voltage is $220 \mathrm{~V}$, and the electrical power is $350 \mathrm{~W} / \mathrm{m}^{2}$. The airport asphalt pavement is exposed in the outdoor environment, which is near Beijing Capital International Airport.

3.1. Deicing and Asphalt Pavement Temperature. On January $22,2014,0^{\circ} \mathrm{C}$ water was evenly sprayed on the $1 \#$ airport asphalt pavement in the experiment, the amount of which was $3 \mathrm{~mm} / \mathrm{m}^{2}$. When the time was from 0:00 to 7:30, water was frozen into ice because the air temperature was always below $0^{\circ} \mathrm{C}$, and then the asphalt pavement began to be energized and heated. No ice was on the 2\# airport asphalt 


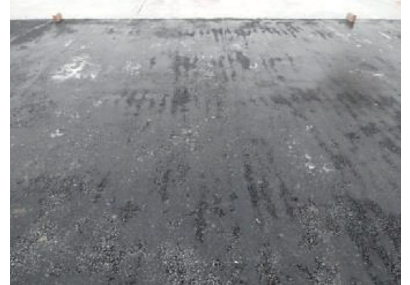

(a)

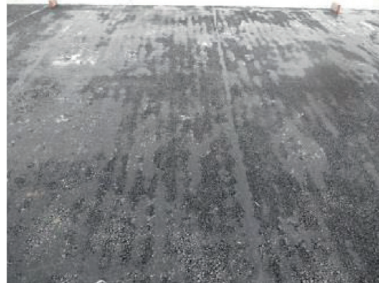

(b)

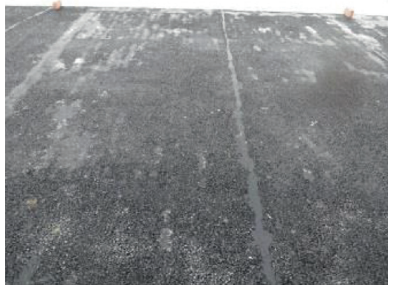

(c)

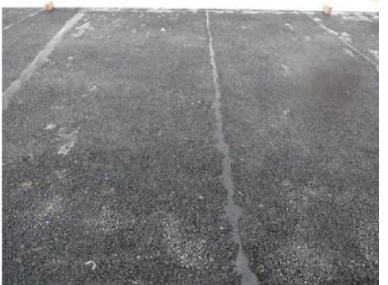

(d)

Figure 4: Melting ice on the 1\# airport asphalt pavement. (a) 90 minutes. (b) 110 minutes. (c) 130 minutes. (d) 150 minutes.

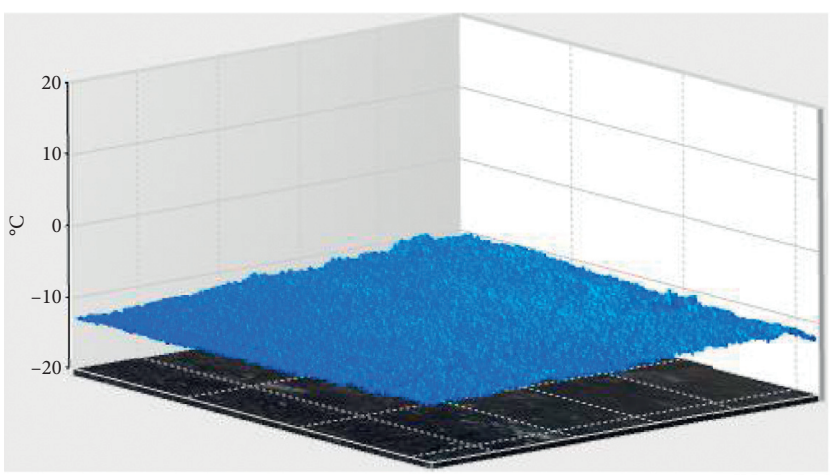

(a)

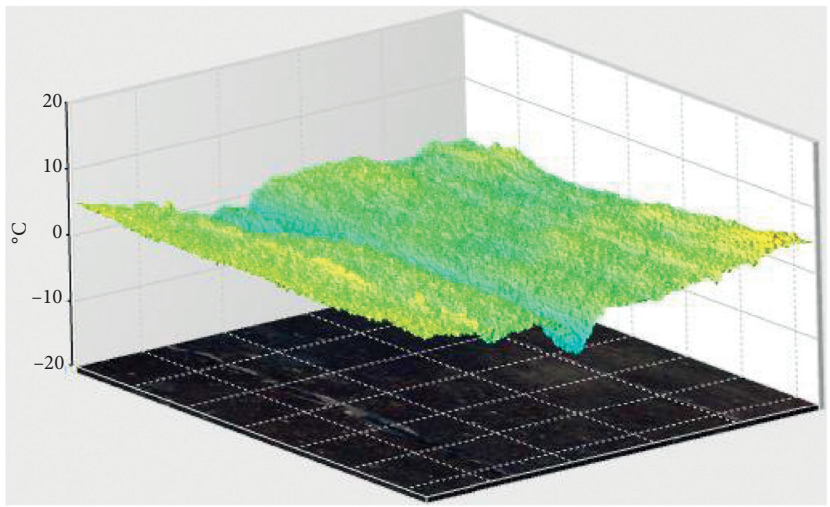

(c)

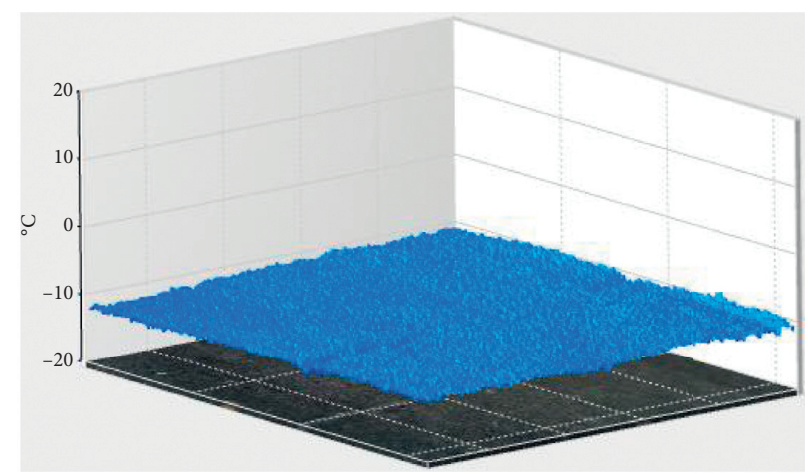

(b)

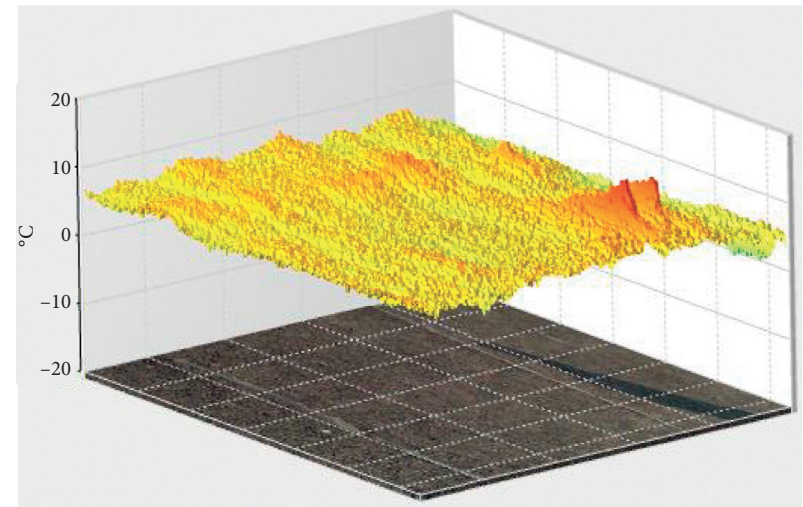

(d)

FIGURE 5: The IRT of the asphalt pavement surface. (a) Initial time (1\# asphalt pavement). (b) Initial time (2\# asphalt pavement). (c) 150 minutes (1\# asphalt pavement). (d) 150 minutes (2\# asphalt pavement).

pavement. The wind speed and relative humidity were $1.0-2.4 \mathrm{~m} / \mathrm{s}$ and $30 \%-45 \%$, respectively. Figure 2 shows that the air temperature raises from $-7.5^{\circ} \mathrm{C}$ to $-2.2^{\circ} \mathrm{C}$ in 150 minutes. The solar radiation intensity is $0-60 \mathrm{~W} / \mathrm{m}^{2}$ in Figure 3.

Figure 4 shows the process of deicing on the 1 \# airport asphalt pavement. Ice begins to melt at 90 minutes. In the paper, the evaluation criterion for the performance of deicing is ice-free area ratio, which is the ratio of the ice-free area to the total area. At 90 minutes, 110 minutes, 130 minutes, and 150 minutes, the ice-free area ratio is $0,0.25$, 0.78 , and 1 , respectively. Ice on the $1 \#$ airport asphalt pavement is completely melted in 150 minutes. It can be seen that the ice melts faster in the later stage.
The asphalt pavement surface temperature is accurately measured by using the infrared thermal image instrument. Figure 5 shows the IRT of the airport asphalt pavement surface at the beginning and end of heating. At the beginning of heating, the IRT of the 1 \# asphalt pavement surface is from $-12.7^{\circ} \mathrm{C}$ to $-10.1^{\circ} \mathrm{C}$, and the average IRT is $-11.5^{\circ} \mathrm{C}$. The IRT of the $2 \#$ asphalt pavement surface is from $-12.4^{\circ} \mathrm{C}$ to $-9.9^{\circ} \mathrm{C}$, and the average IRT is $-11.1^{\circ} \mathrm{C}$. At the end of heating, the asphalt pavement is heated for 2.5 hours. The IRT of the $1 \#$ asphalt pavement surface is from $0.1^{\circ} \mathrm{C}$ to $2.8^{\circ} \mathrm{C}$, and the average IRT is $1.5^{\circ} \mathrm{C}$. The IRT of the $2 \#$ asphalt pavement surface is from $4.1^{\circ} \mathrm{C}$ to $8.4^{\circ} \mathrm{C}$, and the average IRT is $6.3^{\circ} \mathrm{C}$.

Figure 6 shows the asphalt pavement temperature variation with heating time at different depths of the pavement. 


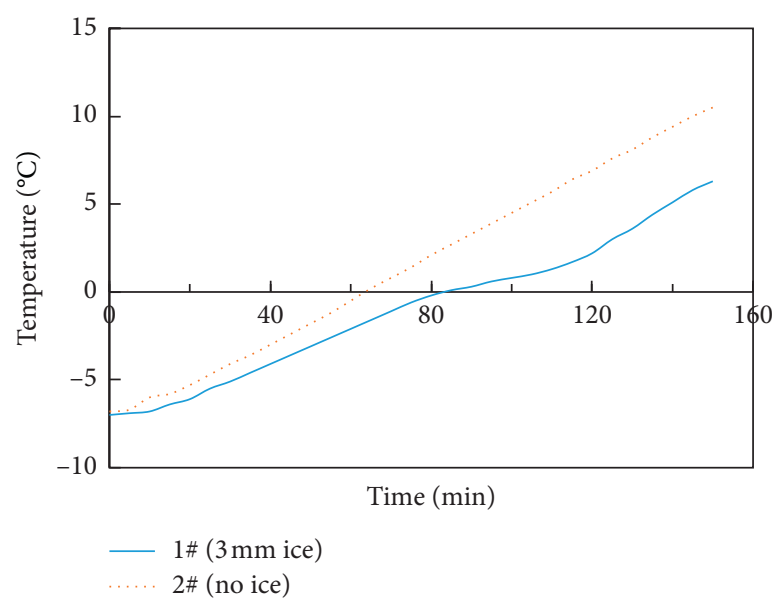

(a)

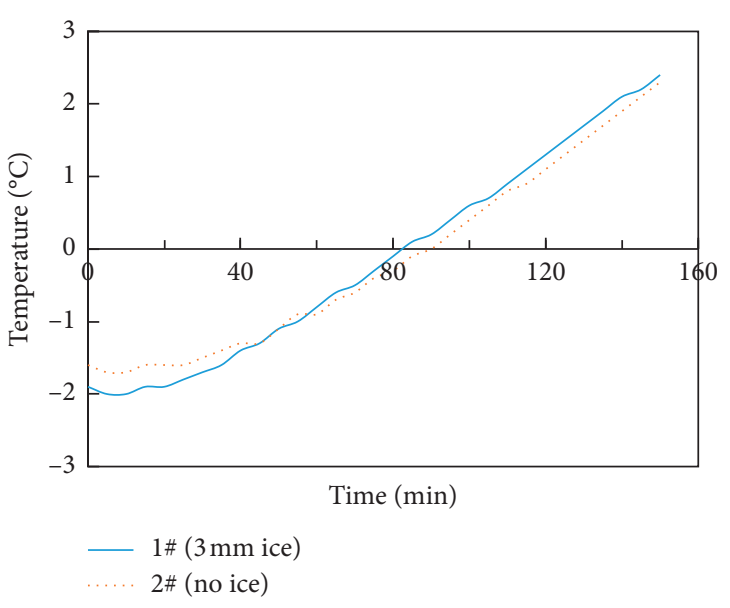

(b)

FIGURE 6: The asphalt pavement temperature variation with heating time. (a) $0.5 \mathrm{~cm}$ depth. (b) $15 \mathrm{~cm}$ depth.

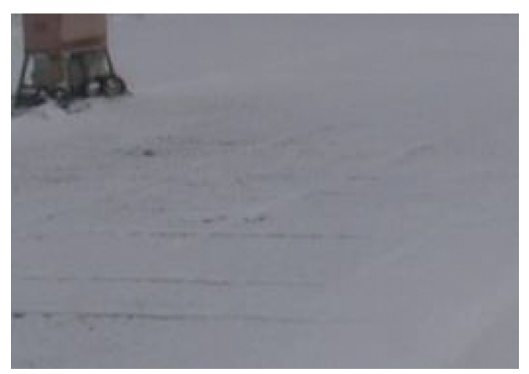

(a)

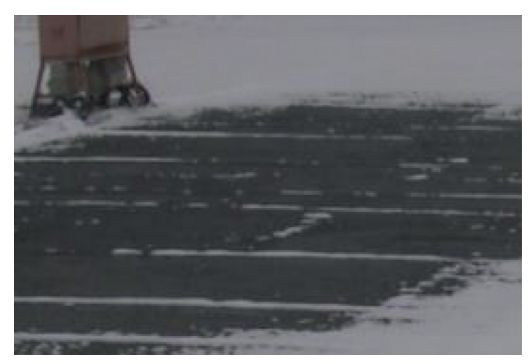

(d)

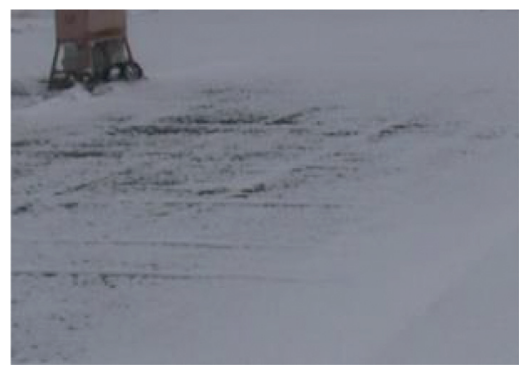

(b)

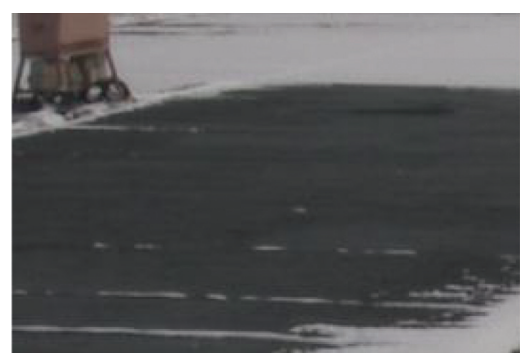

(e)

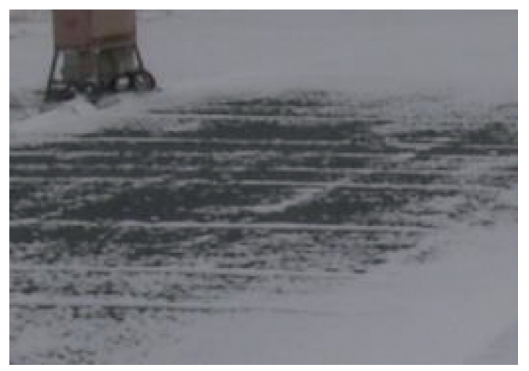

(c)

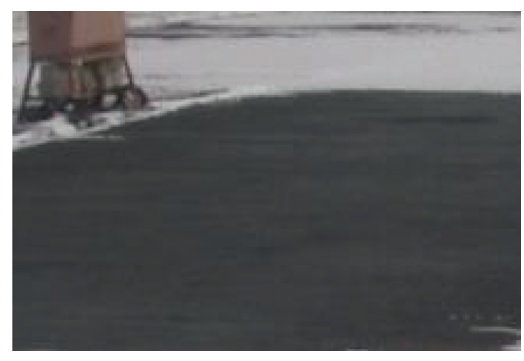

(f)

Figure 7: Melting snow on $1 \#$ asphalt pavement. (a) 60 minutes. (b) 80 minutes. (c) 90 minutes. (d) 100 minutes. (e) 110 minutes. (f) 120 minutes.

As shown in Figure 6(a), the temperature of the 1\# asphalt pavement is always lower than that of the $2 \#$ asphalt pavement at the depth of $0.5 \mathrm{~cm}$ because of the ice on the $1 \#$ asphalt pavement. Their temperature difference increases from $0.2^{\circ} \mathrm{C}$ to $4.7^{\circ} \mathrm{C}$ in 150 minutes. At the depth of $0.5 \mathrm{~cm}$, the heating process of the $1 \#$ asphalt pavement includes three stages: rising stage, stable stage, and rapid rising stage. The asphalt pavement temperature of the rising stage is less than $0^{\circ} \mathrm{C}$. The asphalt pavement temperature of the stable stage is from $0.5^{\circ} \mathrm{C}$ to $2^{\circ} \mathrm{C}$. The asphalt pavement temperature of the rapid rising stage is more than $2^{\circ} \mathrm{C}$. In the process of 150 minutes of heating, it can be seen in Figure 6(b) that $1 \#$ and 2\# asphalt pavement temperature difference at the depth of $15 \mathrm{~cm}$ is less than $0.3^{\circ} \mathrm{C}$ at the same time. At the end of heating, $1 \#$ and 2\# asphalt pavement temperature increases by $4.3^{\circ} \mathrm{C}$ and $3.9^{\circ} \mathrm{C}$, respectively.

\subsection{Melting Snow and Asphalt Pavement Temperature.} Snowfall stopped when the time was 9:00 on January 21, 2016. The accumulated snow thickness is $3 \mathrm{~cm}$. The total precipitation is $3.2 \mathrm{~mm}$. The heating time was from 9:00 to 11:00. The experiment was tested from 9:00 to 11:00. The wind speed and relative humidity were $0.3-1.8 \mathrm{~m} / \mathrm{s}$ and $80 \%-88 \%$, respectively. The air temperature rose from $-4.8^{\circ} \mathrm{C}$ to $-3.5^{\circ} \mathrm{C}$ in 2 hours. The solar radiation intensity was $37-79 \mathrm{~W} / \mathrm{m}^{2}$.

Figure 7 shows the process of melting snow on the 1 \# asphalt pavement. The initial time of melting snow is 60 


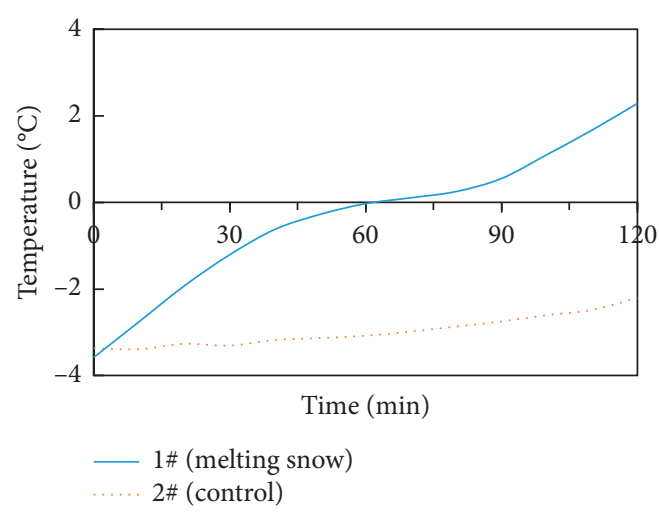

(a)

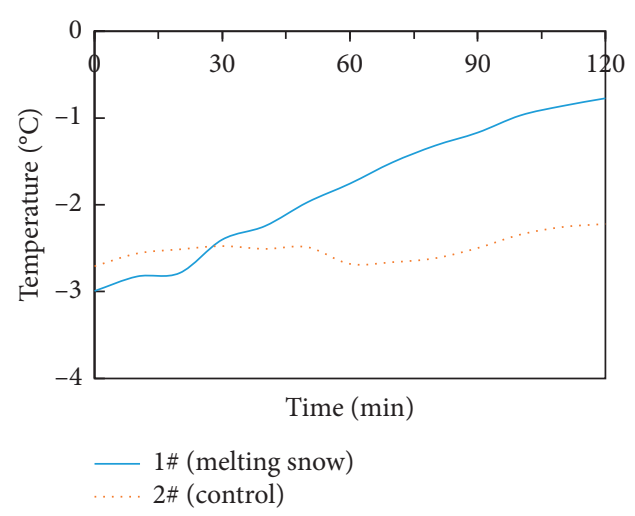

(b)

Figure 8: The asphalt pavement temperature variation with time. (a) $0.5 \mathrm{~cm}$ depth. (b) $15 \mathrm{~cm}$ depth.

minutes. The snow-free area ratio is $0,0.02,0.21,0.72,0.94$, and 1 at 60 minutes, 80 minutes, 90 minutes, 100 minutes, 110 minutes, and 120 minutes, respectively. Most of the snow is melted from 60 minutes to 100 minutes. Snow on the $1 \#$ asphalt pavement is completely melted in 120 minutes. The control group is the $2 \#$ asphalt pavement that is not heated. At the depth of $0.5 \mathrm{~cm}$, it can be seen in Figure 8(a) that $1 \#$ asphalt pavement temperature increases from $-3.6^{\circ} \mathrm{C}$ to $2.3^{\circ} \mathrm{C}$ in 120 minutes because of heating; $2 \#$ asphalt pavement temperature increases from $-3.4^{\circ} \mathrm{C}$ to $-2.2^{\circ} \mathrm{C}$ in 120 minutes because of weather condition. $1 \#$ asphalt pavement temperature curves of melting snow and ice are similar. $1 \#$ asphalt pavement temperature for melting snow includes three stages that are the rising stage, stable stage, and rapid rising stage. At the depth of $15 \mathrm{~cm}$, it can be seen in Figure $8(\mathrm{~b})$ that $1 \#$ asphalt pavement temperature increases from $-3.0^{\circ} \mathrm{C}$ to $-0.8^{\circ} \mathrm{C}$ in 120 minutes, and $2 \#$ asphalt pavement temperature is between $-2.7^{\circ} \mathrm{C}$ and $-2.2^{\circ} \mathrm{C}$ in 120 minutes.

\section{Conclusions}

Deicing and melting snow by the CFHW buried in the airport asphalt pavement is studied in the paper. It is practicable for deicing and melting snow that the depth of the CFHW is $7 \mathrm{~cm}$, and the CFHW spacing is $10 \mathrm{~cm}$ in the airport asphalt pavement. According to frozen and snowy weather in Beijing, the electrical power with $350 \mathrm{~W} / \mathrm{m}^{2}$ is input to the airport asphalt pavement for deicing and melting snow in these experiments. The results of the fullscale field experiment show that it is effective for deicing and melting snow on the airport asphalt pavement by the CFHW. When the air temperature is from $-7.5^{\circ} \mathrm{C}$ to $-2.2^{\circ} \mathrm{C}$, $3 \mathrm{~mm}$ ice can be melted in 2.5 hours; the average IRT of the asphalt pavement surface increases by $13.0^{\circ} \mathrm{C}$. When the air temperature is from $-4.8^{\circ} \mathrm{C}$ to $-3.5^{\circ} \mathrm{C}$, snow with $3.2 \mathrm{~mm}$ precipitation can be melted in 2 hours; and the asphalt pavement temperature can achieve an increment of $5.9^{\circ} \mathrm{C}$ at the depth of $0.5 \mathrm{~cm}$. It is an hour when the ice-free area ratio is from 0 to 1 for deicing. It is also an hour when the snowfree area ratio is from 0 to 1 for melting snow. The findings indicate that the technique of deicing and melting snow on the airport asphalt pavement by the CFHW is practicable in actual engineering of the cold zone.

\section{Data Availability}

The data used to support the conclusions of the study are included within the article.

\section{Conflicts of Interest}

The authors declare no conflicts of interest.

\section{Authors' Contributions}

Xin Su and Yong Lai conceived and designed the experiments; Yong Lai and Yan Liu performed the experiments; Yong Lai, Daoxun Ma, and Peng Wang analyzed the data; and Xin Su and Yong Lai wrote the paper.

\section{Acknowledgments}

This work was financially supported by Science and Technology Project of CAAC (MHRD20140107) and Security Capacity Building Project of CAAC (20180275).

\section{References}

[1] Y. Lai, Y. Liu, X. Su, D. X. Ma, and P. Wang, "The influence of heat flux on melting ice on concrete pavement with carbon fibre heating wire," IOP Conference Series: Materials Science and Engineering, vol. 392, pp. 2-6, 2018.

[2] Q. Yang, X. Li, L. Zhang et al., "Performance evaluation of bitumen with a homogeneous dispersion of carbon nanotubes," Carbon, vol. 158, pp. 465-471, 2020.

[3] M. Guo and Y. Tan, "Interaction between asphalt and mineral fillers and its correlation to mastics' viscoelasticity," International Journal of Pavement Engineering, vol. 10, pp. 1-10, 2019.

[4] M. Guo, H. Liu, Y. Jiao et al., "Effect of WMA-RAP technology on pavement performance of asphalt mixture: a state-of-theart review," Journal of Cleaner Production, vol. 266, p. 121704, 2020.

[5] Z. Min, Y. Xia, X. Li, and Z. Tao, "Performances evaluation of epoxy asphalt mixture containing snow-melting agent," 
Construction and Building Materials, vol. 155, pp. 762-769, 2017.

[6] X. B. Liu and J. D. Spitler, "A simulation tool for the design of the hydronic bridge snow melting system," in Proceedings of the 12th International Road Weather Conference, Bingen, Germany, June 2004.

[7] X. B. Liu, S. J. Rees, and J. D. Spitler, "Modeling snow melting on heated pavement surfaces part I: model development," Applied Thermal Engineering, vol. 27, pp. 1115-1124, 2006.

[8] X. Liu, S. J. Rees, and J. D. Spitler, "Modeling snow melting on heated pavement surfaces. Part II: experimental validation," Applied Thermal Engineering, vol. 27, no. 5-6, pp. 1125-1131, 2007.

[9] M. Chen, S. Wu, H. Wang, and J. Zhang, "Study of ice and snow melting process on conductive asphalt solar collector," Solar Energy Materials and Solar Cells, vol. 95, no. 12, pp. 3241-3250, 2011.

[10] H. Xu and Y. Tan, "Modeling and operation strategy of pavement snow melting systems utilizing low-temperature heating fluids," Energy, vol. 80, pp. 666-676, 2015.

[11] C. Y. Tuan and S. Yehia, "Evaluation of electrically conductive concrete containing carbon products for deicing," ACI Materials Journal, vol. 101, pp. 287-293, 2004.

[12] Z. F. Hou, Z. Q. Li, and K. J. Guang, "The joule heating analysis of electrically conductive concrete for roadway deicing system," in Proceedings of the Seventh International Symposium on Structural Engineering for Young Exports, pp. 977-1001, Tianjin, China, 2002.

[13] P. Xie and J. J. Beaudoin, "Electrically conductive concrete and its application in deicing," in Proceedings of the Second CANMET/ACI International Symposium, pp. 399-417, Las Vegas, NV, USA, 1995.

[14] Y. Lai, Y. Liu, and D. Ma, "Automatically melting snow on airport cement concrete pavement with carbon fiber grille," Cold Regions Science and Technology, vol. 103, pp. 57-62, 2014.

[15] H.-M. Zhao, S.-G. Wang, Z.-M. Wu, and G.-J. Che, "Concrete slab installed with carbon fiber heating wire for bridge deck deicing," Journal of Transportation Engineering, vol. 136, no. 6, pp. 500-509, 2010.

[16] H. M. Zhao, Z. M. Wu, S. G. Wang, J. J. Zheng, and G. J. Che, "Concrete pavement deicing with carbon fiber heating wires," Cold Regions Science and Technology, vol. 65, pp. 413-420, 2011.

[17] Y. Lai, Y. Liu, and D. X. Ma, "The Influence of carbon fiber heating wire spacing on concrete pavement temperature," Materials Research Innovations, vol. 85, pp. 804-808, 2016.

[18] Y. Lai, Y. Liu, D. X. Ma, P. Wang, and X. Su, "The Influence of wind speed on melting ice on concrete pavement with carbon fiber heating wire," in Proceedings of the International Workshop on Materials, Chemistry and Engineering, pp. 313-318, Xiamen, China, March 2018.

[19] Y. Liu, Y. Lai, and D. X. Ma, "Melting snow on airport cement concrete pavement with carbon fibre heating wires," Materials Research Innovations, vol. 19, pp. 95-99, 2015. 